\title{
Antioxidant properties and oxidative stability of oregano seed ethanol extract
}

\author{
Chang Hee Han, Min-Ah Kim, Mi-Ja Kim* \\ Department of Food and Nutrition, Kangwon National University, Samcheok 25949, Korea
}

\section{오레가노 종자 에탄올 추출물의 항산화 특성 및 유지 산화안정성에 미치는 영향}

\author{
한창희 · 김민아·김미자* \\ 강원대학교 보건과학대학 식품영양학과
}

\begin{abstract}
This study aimed to evaluate the antioxidant ability and inhibitory effects of oregano seed ethanol extract (OSEE). In vitro antioxidant assays including DPPH radical scavenging and ABTS cation radical scavenging were conducted, and, ORAC, total phenolic content, and FRAP value were determined. In addition, headspace oxygen, conjugated dienoic acid (CDA) value, and $\rho$-anisidine value $(\rho-\mathrm{AV})$ for exploring oxidative stability were examined in an oil system with $100 \mathrm{ppm}$ OSEE. The radical scavenging activities of $125 \mu \mathrm{g} / \mathrm{mL}$ OSEE using DPPH and ABTS were $84.6 \%$ and $32.2 \%$, respectively. ORAC was significantly higher at a concentration of $100 \mathrm{\mu g} / \mathrm{mL}$ of OSEE as compared with the control without OSEE $(p<0.05)$. The antioxidant ability of the sample was concentration dependent manner. Additionally, the total phenolic content and FRAP value of OSEE were $264.64 \mathrm{\mu g} / \mathrm{mL}$ tannic acid equivalent/g extract and $339.78 \mu \mathrm{g} / \mathrm{mL}$ ascorbic acid equivalent/g extract, respectively. CDA and $\rho-A V$ were significantly reduced to $56.3 \%$ and $76.5 \%$, respectively, in $7 \mathrm{~h}$ of oil oxidation in OSEE, as compared with the control oil. OSEE exhibited excellent in vitro antioxidant ability and oxidative stability in the oil matrix. Furthermore, the major volatile compounds of OSEE were limonene, linalool, o-cymene, thymol, a-pinene, and $\gamma$-terpinene. Therefore, it is evident that oregano seed can be used as a functional ingredient in the natural antioxidant market.
\end{abstract}

Key words : oregano seed, ethanol extract, antioxidant, oxidation stability

\section{서 론}

식품에 존재하는 성분들 중 지방은 쉽게 공기 중의 산소, 빛, 열, 금속 등에 의해 산화되어 식품 고유의 품질을 떨어뜨 리는 경우가 많아 지방 성분을 다량 함유하는 있는 가공식 품들 예를 들어 마가린, 식용유지, 마요네즈, 소스, 캔 제품 의 경우 품질 저하를 막기 위해 식품 산화방지제를 첨가하 여 제품을 개발하고 있다. 특히 이러한 유지 함유 가공식품 은 제조 과정 시 고온 가열로 인한 과산화물, 알데하이드

*Corresponding author. E-mail : mijakim@kangwon.ac.kr Phone : 82-33-540-3313, Fax : 82-33-540-3319

Received 2 October 2018; Revised 30 November 2018; Accepted 3 January 2019.

Copyright (c) The Korean Society of Food Preservation. All rights reserved.
및 케톤 등의 물질들이 쉽게 생성되며(1), $140-200^{\circ} \mathrm{C}$ 온도에 서의 지속적인 가열은 유지의 자동산화를 가속화시켜 과산 화물의 생성을 촉진하게 된다. 그러므로 이러한 유지를 함 유한 가공식품 제조 시 식품 산화방지제를 첨가하는데 주로 BHA, BHT 등의 합성 산화방지제가 많이 이용되고 있다. 그러나 장기간 이러한 합성 산화방지제의 다량 섭취가 지방 대사의 불균형과 인체의 내장 조직에 발암을 일으킬 가능이 조심스럽게 제기되고 있어(2), 식품에 첨가 시 산화 방지능 외에도 항균, 항암 등의 기능을 가지는 인체에 무해한 천연 물질을 이용한 식품 산화방지제 개발에 대한 관심이 증가하 고 있는 추세이다(3)

식품뿐만 아니라 일반적으로 인체에서 빈번하게 발생되 는 활성산소종(reactive oxygen species, ROS)은 체내에서 산화적 스트레스에 의해 지질, 단백질, DNA 등 인체 구성 성분에 영향을 미친다(4). 이러한 체내에 발생된 활성산소 
는 체내 산화 방지 시스템에 의해 제거되지만 제거와 생성 의 불균형에 의해 제거되지 않은 활성산소종이 지나치게 과량 존재하게 됨으로써 세포에 산화적 손상을 일으킨다. 그뿐만 아니라 인체 질병 중 약 $90 \%$ 가 활성산소와 관련이 있다고 하며, 알려진 질환에는 주로 암, 동맥경화, 당뇨병, 뇌졸중, 심근경색, 간염, 신장염, 아토피성 피부염, 파킨슨 병 등 노화 관련 질병을 포함한 다양하게 영향을 미치는 것으로 알려져 있다(5-7).

향신료는 예로부터 항균, 산화 방지, 항암, 혈압 강하, 혈청 콜레스테롤 농도 저하, 당뇨병 예방 및 노화 방지 등의 생리작용이 있으며(8-10), 비타민, 무기질이 풍부하고 소화, 수렴, 이뇨, 항균작용 등이 있어 영양과 건강증진에 도움을 준다고 알려져 있다(11). 향신료의 우수한 생리 활성은 alcohol, aldehyde, ester, terpene 및 유기산, 폴리페놀 화합물 등에서 기인하며, 이러한 생리활성물질은 추출 용매에 따 라 추출 수율이 다를 뿐 아니라 항균효과, 산화 방지 활성 또한 달라지는 것으로 보고 되었다(12).

오레가노는 꿀풀과(Lamiaceae)에 속하는 허브식물로 독 특한 향과 맛으로 관상용으로 재배될 뿐 아니라 요리에 향신료로 이용되고 있다. 오레가노로부터 추출한 essential oil은 항 미생물, 항종양 활성을 나타낼 뿐 아니라 에탄올 추출물을 경구투여 시 스트레스성 위염을 억제하는 항염증 효능을 나타내며(13), 항균, 항 돌연변이, 항산화 및 생리활 성 효과가 있음이 밝혀졌다(14). 또한 오레가노 에탄올 추출 물은 자유라디칼 산화 억제 및 지방질 과산화 억제 등에 강력한 산화 방지 효과를 나타낸다고 보고되었는데(15), carvacrol, tymol, pinterpinene 및 linalool이 오레가노에 함유 되어 있어 강력한 항산화능을 가진다고 보고하고 있다(16).

이에 본 연구에서는 오레가노 종자 에탄올 추출물의 천 연 산화방지제로서 사용 가능성을 탐색하기 위하여 산화 방지 활성 및 유지 산화 안정성 개선 효과를 in vitro 시스템 과 식품 모델에서 평가하였다.

\section{재료 및 방법}

\section{오레가노 종자 에탄올 추출물 제조}

오레가노 종자는 터키산으로 $100 \mathrm{~g}$ 당 10 배의 $80 \%$ 에탄 올을 첨가하여 실온에서 진탕기(RS-1, JEIO TECH, Daejeon, Korea)를 이용하여 $274 \mathrm{rpm}$ 속도로 1 시간 진탕한 후, 거름 종이(Whatman No.4, Maidstone, England)로 여과한 후, 여 액을 $60^{\circ} \mathrm{C}$ 수옥상에서 rotary vacuum evaporator(EYELA, Tokyo, Japan)로 용매를 제거하고 감압, 농축한 후 동결 건조하여 $-20^{\circ} \mathrm{C}$ 이하로 냉동 보관하면서 시료로 사용하였다.

\section{2,2-Diphenyl-1-picrylhydrazyl(DPPH) 라디칼 소거활성} $\mathrm{DPPH}$ 라디칼 소거 활성은 Blois(17)의 방법에 따라 0.1
$\mathrm{mM}$ 의 DPPH(Sigma-Aldrich Co., St. Louis, MO, USA) 용액 $0.75 \mathrm{~mL}$ 에 추출물을 $31.25,62.50,125.00 \mathrm{\mu g} / \mathrm{mL}$ 의 농도로 증류수에 희석한 시료를 각 $0.25 \mathrm{~mL}$ 씩 넣고 10 초간 혼합하 여 30분간 암실에서 반응시킨 후 UV/VIS spectrophotometer (Mega- U6000, Scinco, Seoul, Korea)를 이용하여 $517 \mathrm{~nm}$ 에 서 흡광도를 측정하였다. DPPH 라디칼 소거 활성은 시료의 첨가 전과 후의 차이를 아래와 같이 백분율로 나타내었다.

$$
\text { DPPH radical scavenging activity }(\%)=\frac{\text { Ac-As }}{\mathrm{Ac}} \times 100
$$

$\mathrm{Ac}$ : 대조군의 흡광도

As : 시료의 흡광도

\section{2,2'-Azino-bis (3-ethylbenzothiazoline-6-sulphonic} acid) (ABTS) 양이온 라디칼 소거활성

$\mathrm{ABTS}$ 양이온 라디칼 소거 활성은 $\operatorname{Re}$ 등(18)의 방법에 따라 $7 \mathrm{mM}$ 의 ABTS(Sigma-Aldrich Co.) 수용액과 $2.45 \mathrm{mM}$ potassium persulfate(Sigma-Aldrich Co.)를 1:1로 혼합하여 상온 암실에서 12시간 방치하여 $\mathrm{ABTS}$ 라디칼 양이온을 형성한 후 $734 \mathrm{~nm}$ 에서 UV/VIS spectrophotometer(Mega$\mathrm{U} 6000, \mathrm{Scinco})$ 를 이용하여 흡광도가 $0.700( \pm 0.050)$ 이 되도 록 에탄올로 희석하여 사용하였다. 희석된 ABTS 용액 1.9 $\mathrm{mL}$ 과 농도별 추출물 시료 $0.05 \mathrm{~mL}$ 를 가하여 혼합한 후 6 분간 상온 암실에서 정치한 후 $734 \mathrm{~nm}$ 에서 흡광도를 측정 하였다.

$$
\text { ABTS radical scavenging activity }(\%)=\frac{\text { Ac-As }}{\text { Ac }} \times 100
$$

$\mathrm{Ac}$ : 대조군의 흡광도

As : 시료의 흡광도

\section{Oxygen radical absorbance capacity (ORAC) 측정} ORAC 법은 Prior 등(19)의 방법에 의해 실험하였다. 시료 및 대조군의 희석과 시약의 제조는 $75 \mathrm{mM}$ phosphate buffer(pH 7.0)을 이용하였다. 2,2'azo-bis(2-amidino-propane) dihydrochloride(AAPH)(FUJIFILM Wako Pure Chemical Corporation, Osaka, Japan) $300 \mathrm{mM}$ 과 fluorescein 용액 0.1 $\mathrm{mM}$, 시료를 각 $2.5,5,10 \mathrm{\mu g} / \mathrm{mL}$ 농도로 $75 \mathrm{mM}$ phosphate buffer에 희석하여 사용하였다. 추출물의 농도별 시료, fluorescein 용액, AAPH를 5:15:5(v/v/v)의 비율로 96-well plate에 넣어 fluorescence microplate reader(GeminiXPS, Moleculardevice, Sanjose, CA, USA)를 이용하여 excitation $493 \mathrm{~nm}$, emission $515 \mathrm{~nm}$ 에서 40 분간 매분 측정하였으며 대조군으로는 trolox(Sigma-Aldrich Co.)를 사용하였다. 결 과는 시료 첨가군과 무첨가군의 커브면적(area under curve, 
AUC)을 측정한 후 $\mu \mathrm{g} / \mathrm{mL}$ trolox equivalent $/ \mathrm{g}$ 으로 표기하였 다.

Ferric reducing antioxidant power(FRAP) 환원력

FRAP 환원력은 Benzie와 Strain(20)의 방법을 변형하여 $300 \mathrm{mM}$ sodium acetate buffer(pH 3.6), $40 \mathrm{mM} \mathrm{HCl}$ 에 용해한 $10 \mathrm{mM}$ 2,4,6-tripyridyl-S-triazine(TPTZ)용액 및 $20 \mathrm{mM}$ $\mathrm{FeCl}_{3}$ 를 각각 $10: 1: 1(\mathrm{v} / \mathrm{v} / \mathrm{v})$ 의 비율로 혼합하여 $37^{\circ} \mathrm{C}$ 수조에 서 10-15분간 평형시켜 FRAP 시약을 제조하였다. 농도를 다르게 만든 시료 각 $0.03 \mathrm{~mL}$ 와 FRAP 시약 $0.9 \mathrm{~mL}$ 를 혼합 하여 30 분간 반응시킨 후 $593 \mathrm{~nm}$ 에서 UV/VIS spectrophotometer(Mega-U6000, Scinco)를 이용하여 흡광 도를 측정하였다. 시료의 FRAP 환원력은 ascorbic acid (Sigma-Aldrich Co.) 표준곡선으로부터 계산하였다.

\section{총 페놀 함량 측정}

총 페놀 함량(TPC)은 Folin과 Denis(21)법에 따라 농도 별로 희석한 시료 $0.25 \mathrm{~mL}$ 와 증류수 $4 \mathrm{~mL}$, 증류수와 $1: 1$ 로 희석한 Folin-Denis 시약(Sigma-Aldrich Co.) $0.25 \mathrm{~mL}$ 을 가 한 용액을 3 초간 혼합한 후 5 분간 정치하였다. 혼합한 용액 에 sodium carbonate(Sigma-Aldrich Co.) $0.5 \mathrm{~mL}$ 을 가하여 혼합한 후 상온에서 30 분간 정치하여 UV/VIS spectrophotometer(Mega-U6000, Scinco)를 이용하여 725 $\mathrm{nm}$ 에서 흡광도를 측정하였다. 표준물질 tannic acid (Sigma-Aldrich Co.)를 이용하여 작성한 표준곡선으로부터 총 페놀 함량을 계산하였다.

\section{휘발성 물질 추출 분리}

불꽃이온화 검출기(flame ionization detector, FID)를 설 치한 GC(Hewlett-Packard 6890, Agilent Technology, Palo Alto, CA, USA)를 이용하여 SPME fiber로 휘발성 물질을 분리하였다. SPME fiber는 $65 \mu \mathrm{m}$ polydimethylsiloxane/ divinylbenzene(PDMS/DVB, Supelco, Bellefonte, PA, USA) 을 사용하였으며, 고정상으로는 $\mathrm{HP}-5(30 \mathrm{~m} \times 0.32 \mathrm{~m} \mathrm{ID}, 0.25$ $\mathrm{mm}$ film, Agilent Technology) 칼럼을 사용하였다. 온도 조 건은 초기에 $40^{\circ} \mathrm{C}$ 에서 2 분간 방치하고 분당 $6^{\circ} \mathrm{C}$ 씩 최종 $160^{\circ} \mathrm{C}$ 로 증가시켰다. 주입기의 온도는 $250^{\circ} \mathrm{C}$, 검출기는 30 $0^{\circ} \mathrm{C}$ 로 설정하였으며, 운반 가스로는 질소를 이용하여 유속 은 $1.0 \mathrm{~mL} / \mathrm{min}$ 으로 설정하였다.

\section{휘발성 성분 분석}

GC-mass spectrometry(5971A, Agilent Technology)를 사 용하여 휘발성 물질을 동정하였으며, 추출 조건은 GC-FID 와 동일한 조건으로 사용하였다. 이동상으로는 헬륨가스를 사용하여 $1.0 \mathrm{~mL} / \mathrm{min}$ 의 유속으로 흘려주었다. $\mathrm{MS}$ 의 분석 조건은 $70 \mathrm{ev}, 220$ ion source 온도를 사용하였으며, NIST 질량스펙트럼 라이브러리(mass spectra library)와 대조군의
머무름 시간(retention time)을 이용하여 휘발성분을 동정하 였다.

\section{오레가노 종자 에탄올 추출물 첨가 유지 제조}

유지 시료는 오레가노 종자 에탄올 추출물의 고른 분산 을 위해 dimethyl sulfoxide(DMSO)에 녹여 옥수수기름 (Ottogi, Anyang, Korea)과 혼합하여 사용하였으며, DMSO 가 산화 안정성에 영향을 미칠 수 있어 대조군 또한 DMSO 를 첨가하여 실험하였다. 제조된 시료는 유지의 산화를 방 지하기 위해 $-20^{\circ} \mathrm{C}$ 에서 보관하며 실험하였다.

\section{Headspace oxygen 함량}

Headspace oxygen 함량은 $\mathrm{Kim}$ 등(22) 방법에 따라 GC-TCD(Agilent Technology Inc., Santa Clara, CA, USA)를 사용하였다. 시료가 포함된 유지 $1 \mathrm{~g}$ 을 gas-tight vial에 취하 여 $100{ }^{\circ} \mathrm{C}$ 오븐(GISICO, Seoul, Korea)에서 6시간, 12 시간, 18 시간 산화시켜 사용하였다. Air-tight syringe로 $20 \mu \mathrm{L}$ 의 headspace gas를 60/80 packed column(3.0 m×2 mm ID; Restek Ltd., Bellefonte, PA, USA)과 thermal conductivity detector(TCD)가 장착되어 있는 Hewlett-Packard 7890 gas chromatograph(Agilent Technology)에 주입하였다. 이동상 인 헬륨 가스는 $20 \mathrm{~mL} / \mathrm{min}$ 의 속도로 주입되었고, $\mathrm{GC}$ 의 오븐, 주입구, 검출기의 온도는 각각 $60,180,180^{\circ} \mathrm{C}$ 로 설정 하여 산소 함량 \%로 나타내었다.

\section{Conjugated dienoic acid(CDA) 가}

추출물을 각 농도 별로 혼합하여 산화시킨 유지 시료 $100 \mathrm{mg}$ 을 $25 \mathrm{~mL}$ isooctane(Sigma-Aldrich Co.)으로 분산 및 적정 농도로 희석한 후 UV/VIS spectrophotometer(Mega$\mathrm{U} 6000, \mathrm{Scinco}$ )를 이용하여 AOCS 법(23)에 의해 $233 \mathrm{~nm}$ 에 서 흡광도를 측정하였다.

$$
\text { CDA value }(\%)=\frac{0.84 \times \mathrm{A}_{233}}{\mathrm{bc}-\mathrm{K}_{0}}
$$

$\mathrm{K}_{0}: \mathrm{acid}$ 의 흡광도 계수(0.03)

$\mathrm{A}_{233}: 233 \mathrm{~nm}$ 에서의 흡광도

$\mathrm{b}$ : cell의 길이 $(\mathrm{cm})$

$\mathrm{c}$ : L당 시료의 무게 $(\mathrm{g})$

\section{$\mathrm{p}$-Anisidine value ( $\mathrm{p}-\mathrm{AV}$ )}

$\rho-\mathrm{AV}$ 는 AOCS 법(24)에 의해 실시하였다. 시료를 4,000 $\mathrm{ppm}$ 의 농도로 isooctane(Sigma-Aldrich Co.)에 분산시킨 시 료 $1 \mathrm{~mL}$ 와 $0.25 \%$ p-anisidine(Sigma-Aldrich Co.) 용액 0.2 $\mathrm{mL}$ 를 넣고 혼합하여 15 분간 암실에서 반응시킨 후 UV/VIS spectrophotometer (Mega-U6000, Scinco)를 이용하여 350 $\mathrm{nm}$ 에서 흡광도를 측정하여 $\mathrm{p}-\mathrm{AV}$ 로 환산하였다. 


\section{통계처리}

3회 반복 실험하여 얻은 결과는 SPSS program(SPSS Inc., Chicago, IL, USA)을 이용하여 평균표준편차로 나타내었 다. 유의성 검정은 t-test 및 one-way ANOVA로 분석하여 $\mathrm{p}<0.05$ 수준에서 Duncan's multiple range test로 사후 검증 하였으며, 상관관계지수는 피어슨 상관계수(Pearson correlation coefficient)를 이용하여 유의성 검정을 실시하였다.

\section{결과 및 고찰}

오레가노 에탄올 추출물의 DPPH 라디칼 및 $\mathrm{ABTS}$ 양이온 라디칼 소거 활성

오레가노 종자 에탄올 추출물의 라디칼 소거 활성은 Fig. 1 과 같다. $31.25,62.50,125 \mu \mathrm{g} / \mathrm{mL}$ 의 농도로 제조하여 실험 한 결과 DPPH 라디칼 소거활성은 각 $23.3,46.9,84.6 \%$ 로 측정되었으며, $\mathrm{ABTS}$ 양이온 라디칼 소거 활성의 경우 각각 $8.4,16.1,32.2 \%$ 의 라디칼 소거능을 나타내어 농도 의존적 으로 증가한 양상을 보였다 $(\mathrm{p}<0.05)$.

Rhim과 Choi(25)의 연구에서 오레가노 에탄올 추출물이 $125 \mathrm{\mu g} / \mathrm{mL}$ 농도에서 $82.7 \%$ 의 라디칼 소거능을 보고하여 본 연구와 유사한 경향을 나타내었다. Cha 등(26)의 연구에 따르면 오레가노의 추출 용매에 따른 $\mathrm{DPPH}$ 라디칼 소거 활성과 $\mathrm{ABTS}$ 라디칼 소거능을 비교한 결과 $\mathrm{DPPH}$ 라디칼 소거능은 물 추출이 높았으나 $\mathrm{ABTS}$ 라디칼 소거 활성은 유의적 차이가 나타나지 않는 것으로 보고하였으며 향신료 의 일종인 thyme의 열수 추출물이 알코올 추출물보다 산화 방지능이 높은 것으로 보고(27) 하여 향신료마다 추출 조건 에 따라 추출 성분이 달라져 라디칼 소거 활성에 차이가 있는 것으로 나타났다. 이외에도 다른 식용식물들의 라디 칼 소거 활성에 대한 연구를 보면 에탄올로 추출한 고려엉

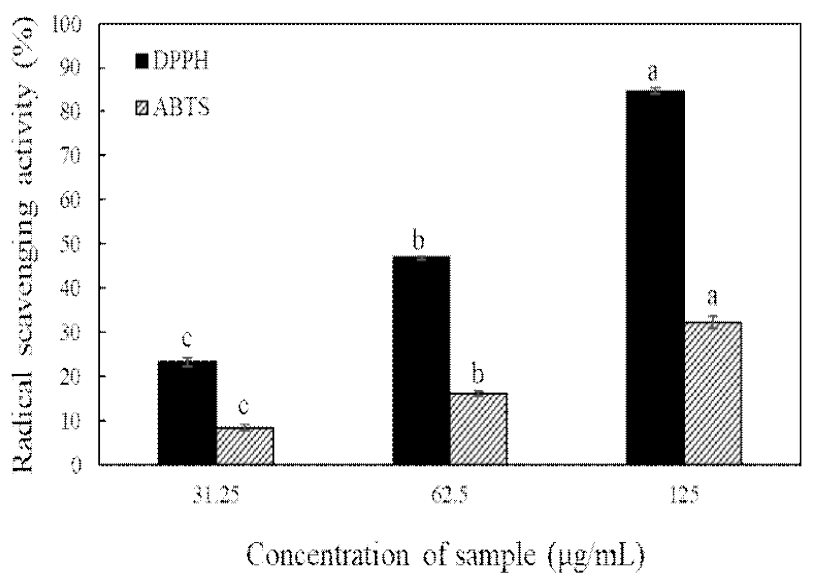

Fig. 1. Radical scavenging activities of oregano seed ethanol extract. Different letters are significantly different at $p<0.05$ among different treatment concentration in each group.
겅퀴는 $12.5 \mathrm{mg} / \mathrm{mL}$ 의 농도에서 $31.25-81.93 \%(28)$, 씀바귀 는 $1 \mathrm{mg} / \mathrm{mL}$ 의 농도에서 $24.62 \%$ 의 라디칼 소거능을 가진다 고 보고(29) 하여 식용식물들이 다양한 라디칼 소거 활성을 보이는 것으로 사료된다.

\section{오레가노 에탄올 추출물의 ORAC 가에 미치는 영향}

ORAC법은 peroxy radical에 의해 fluorescence 감소를 측 정하여 산화 방지능을 평가하는 방법이다. Fig. $2 \mathrm{~A}$ 는 오레 가노 종자 에탄올 추출물을 $2.5,5,10 \mu \mathrm{g} / \mathrm{mL}$ 농도로 희석하 여 나타낸 것으로 농도 의존적인 경향을 보였다. Fig. 2B는 대조군에 비해 trolox $6.26 \mu \mathrm{g} / \mathrm{mL}$ 처리 군에서 2.1배, 오레가 노 종자 에탄올 추출물 $10 \mu \mathrm{g} / \mathrm{mL}$ 농도에서 대조군에 비해 약 1.9 배 높게 나타나 $(\mathrm{p}<0.05)$ 천연 항산화제로서 합성 항산 화제를 대체할 수 있을 것으로 생각된다. Kratchanova 등 (30)은 25 가지 불가리아의 약용작물을 서로 다른 극성을

(A)

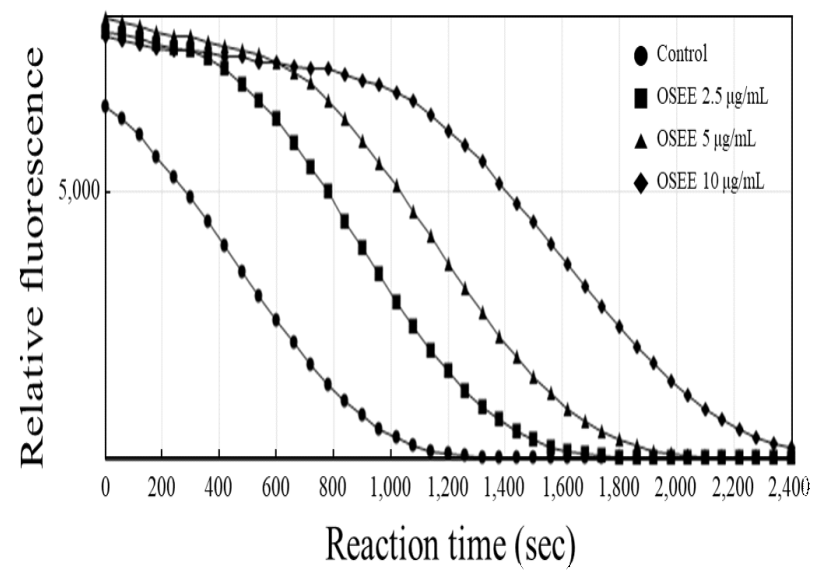

(B)

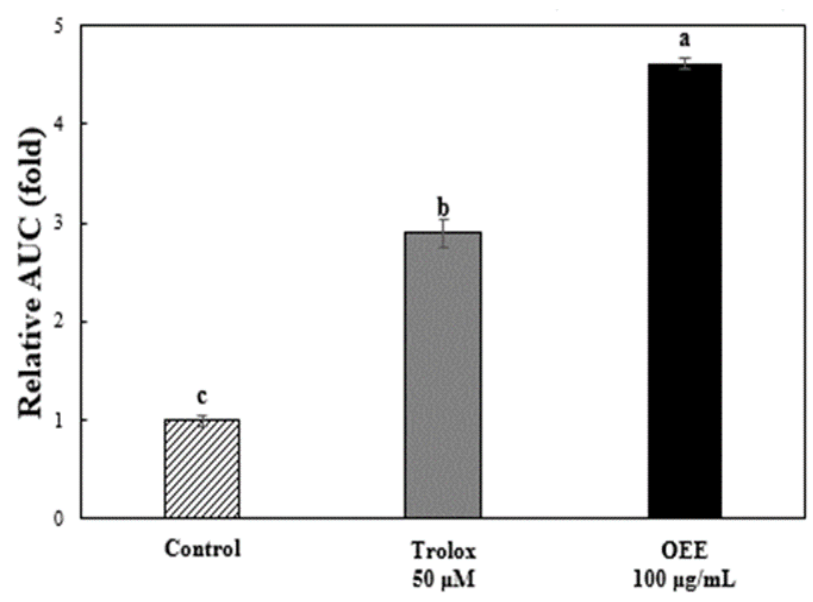

Fig. 2. Effect of oregano seed ethanol extract on fluorescein elimination induced by AAPH.

A, Time course of the reaction of fluorescein with AAPH in the absence and in the presence of oregano ethanol extract at different; B, Values represent the mean \pm SD $(n=3)$. Different letters above a bar are significantly different at $\mathrm{p}<0.05$. OSEE, oregano seed ethanol extract. 
가진 용매인 물과 아세톤으로 추출하여 ORAC 가를 서로 비교한 결과 아세톤 추출물이 물 추출물 보다 산화 방지 활성이 우수하였고, 아세톤 추출물 중에서는 peppermint 가 2,917 umol trolox equivalent/g dry weight로 나타나 가장 우수하였으며 총 페놀 함량도 가장 우수한 것으로 나타났 고, 물 추출물 중에는 thyme이 $1,434 \mu \mathrm{mol}$ trolox equivalent $/ \mathrm{g}$ dry weight로 나타나 본 연구와 같이 향신료들이 우수한 ORAC 가를 보이는 것으로 나타났다.

\section{오레가노 종자 에탄올 추출물의 총 페놀 함량 및 FRAP 환원력}

오레가노 종자 에탄올 추출물의 총 페놀 함량 및 FRAP 환원력의 결과는 Table 1 과 같다. 총 페놀 함량은 264.64 $\mathrm{\mu g} / \mathrm{mL}$ tannic acid equivalent/g extract로 나타났으며, FRAP 환원력은 $339.78 \mathrm{\mu g} / \mathrm{mL}$ ascorbic acid equivalent/g extract로 나타났다. $\mathrm{Su}$ 등(31)에 의하면 오레가노 잎 $50 \%$ 아세톤 추출물을 표준물질 gallic acid로 환산한 총 페놀 함량은 $5.48 \mathrm{mg} / \mathrm{g}$ 로 보고하였으며, $\mathrm{Ahn}$ (32)은 오레가노 잎의 추출 용매에 따른 총 페놀 함량을 비교한 결과 메탄올 추출물이 $11,471 \mathrm{mg} \%$, 에틸 아세테이트 추출물이 $13,893 \mathrm{mg} \%$, 헥산 추출물은 $1,483 \mathrm{mg} \%$ 로 나타나 에틸 아세테이트 추출조건 이 가장 다량의 총 페놀 화합물을 추출할 수 있는 조건으로 보고한 바 있다.

Table 1. Total phenolics and FRAP value of oregano seed ethanol extract

\begin{tabular}{ccc}
\hline & $\begin{array}{c}\left.\mathrm{TPC}^{1}\right) \\
(\mu \mathrm{g} / \mathrm{mL} \text { tannic acid equivalent/g } \\
\text { extract) }\end{array}$ & $\begin{array}{c}\mathrm{FRAP}^{2)} \\
(\mu \mathrm{g} / \mathrm{mL} \text { ascorbic acid equivalent/g } \\
\text { extract) }\end{array}$ \\
\hline $\mathrm{OSEE}^{3)}$ & $264.64 \pm 15.23$ & $339.78 \pm 12.81$
\end{tabular}

${ }^{1)}$ TPC, total phenolic contents.

${ }^{2}$ FRAP, ferric reducing antioxidant power.

${ }^{3)}$ OSEE, oregano seed ethanol extract.

오레가노 종자 에탄올 추출물의 총 페놀 함량과 산화 방 지 분석법과의 상관관계

오레가노 종자 에탄올 추출물의 산화 방지 측정법과 총
페놀 함량의 상관관계 분석 결과는 Table 2 와 같다. $\mathrm{TPC}$ 와 $\mathrm{DPPH}$ 라디칼 소거 활성은 $\mathrm{r}=1.000(\mathrm{p}<0.01), \mathrm{ABTS}$ 양이온 라디칼 소거 활성은 $\mathrm{r}=0.994(\mathrm{p}<0.01), \mathrm{FRAP}$ 환원력은 $\mathrm{r}=0.995$ ( $\mathrm{p}<0.01)$, ORAC assay는 $\mathrm{r}=0.972(\mathrm{p}<0.01)$ 로 모두 유 의적 상관관계를 나타내어 총 페놀 함량이 증가할수록 산화 방지에 효과가 있는 것으로 나타났다. Surveswaran 등(33) 의 연구에 따르면 인도산 약용식물 113 종의 산화 방지 활성 과 총 페놀 함량과의 상관관계를 비교하였을 때, $\mathrm{DPPH}$ 산화 방지 활성과의 상관성은 $\mathrm{r}=0.9378(\mathrm{p}<0.001), \mathrm{ABTS}$ 양 이온 라디칼 소거 활성은 $\mathrm{r}=0.9690(\mathrm{p}<0.001), \mathrm{FRAP}$ 환원력 은 $\mathrm{r}=0.8941(\mathrm{p}<0.001)$ 로 양의 상관관계를 나타내었다. Zheng과 Wang(34)의 연구에 따르면 오레가노를 포함하여 thyme, dill, peppermint, sage, basil, fennel등 39종의 신선한 허브와 조리한 허브의 산화 방지 효과에 대한 연구로 총 페놀 함량과 $\mathrm{ORAC}$ 가의 상관관계는 $\mathrm{r}=0.984$ 로 허브의 페 놀 화합물이 산화 방지 효과에 큰 기여를 했다고 보고하였 다. 따라서 본 연구에서도 총 페놀 함량과 $\mathrm{DPPH}$ 라디칼 소거 활성, $\mathrm{ABTS}$ 양이온 라디칼 소거 활성, $\mathrm{FRAP}$ 환원력 및 $\mathrm{ORAC}$ 법이 양의 상관관계를 나타내어 오레가노 종자 에탄올 추출물의 산화 방지 활성은 총 페놀 함량의 증가에 의한 것으로 생각된다.

\section{향기성분분석}

오레가노 종자 에탄올 추출물의 휘발성 물질은 Table 3 과 같이 주요 휘발성 물질은 limonene, linalool, o-cymene, thymol, a-pinene, $\gamma$-terpinene 등이 검출되었다. Lopez 등 (35)은 정유성분에서 carvacrol, $\rho$-cimeme, linalool, $\gamma$ -terpinene 등이 검출되었다고 보고하여 유사한 결과를 보였 다. 오레가노 종자 에탄올 추출물에서 limonene, linalool, O-cymene, thymol, thymol, a-pinene, $\gamma$-terpinene은 (21.56 $\pm 2.82,16.5 \pm 0.14,12.56 \pm 1.62,7.81 \pm 0.04,4.47 \pm 0.21$, $4.24 \pm 0.52) \times 10^{6}$ peak area를 보였으며 각각의 peak는 $24.9 \%$, $19.1 \%, 14.5 \%, 9.0 \%, 5.2 \%, 4.9 \%$ 의 함량을 갖고 있는 것으로 나타났다.

Baratta 등(36)은 오레가노 외 5종의 오일을 Acinetobacter calcoaceticus 외 24 종의 박테리아와 곰팡이를 이용하여

Table 2. Correlation of oregano seed ethanol extract among total phenolic content and antioxidant activity

\begin{tabular}{cccccc}
\hline & $\begin{array}{c}\text { DPPH radical scavenging } \\
\text { activity }\end{array}$ & $\begin{array}{c}\text { ABTS cation radical scavenging } \\
\text { activity }\end{array}$ & FRAP & ORAC & Total phenolic content \\
\hline $\begin{array}{c}\text { DPPH radical scavenging activity } \\
\text { ABTS cation radical scavenging }\end{array}$ & 1 & & & \\
activity & $0.994^{* * 1}$ & 1 & 1 & \\
FRAP & $0.998^{* *}$ & $0.991^{* *}$ & $0.981^{* *}$ & 1 & $0.972^{* *}$ \\
ORAC & $0.975^{* *}$ & $0.959^{* *}$ & $0.997^{* *}$ & 1 \\
Total phenolic content & $1.000^{* *}$ & $0.944^{* *}$ & & & \\
\hline
\end{tabular}


Table 3. The volatile compounds of oregano seed ethanol extract analyzed by GC-MS

\begin{tabular}{|c|c|}
\hline Volatile compounds & $\begin{array}{l}\text { Peak area } \\
(\%)^{1)}\end{array}$ \\
\hline 1-Methyl-4-(1-methylethenyl) cyclohexene (limonene) & $21.56 \pm 2.82(24.9)$ \\
\hline 3,7-Dimethylocta-1,6-dien-3-ol (inalool) & $16.5 \pm 0.14(19.1)$ \\
\hline 1-Methyl-2-Isopropylbenzene (o-cymene) & $12.56 \pm 1.62(14.5)$ \\
\hline 2-Isopropyl-5-methyl-phenol (thymol) & $7.81 \pm 0.04(9.0)$ \\
\hline 2,6, 6-Trimetylbicyclo[3.1.1]-2-hept-2-ene (a-pinene) & $4.47 \pm 0.21(5.2)$ \\
\hline 1-Isopropyl-4-methyl-1,4-cyclohexadiene ( 8 -terpinene) & $4.24 \pm 0.52(4.9)$ \\
\hline Trans-2-methyl-2-butenal (tiglaldehyde) & $3.75 \pm 0.19(4.3)$ \\
\hline Hexanal & $3.66 \pm 0.24(4.2)$ \\
\hline 1-Isopropyl-4-methylenbicyclo[3.1.0]hexane ((+)-sabinene) & $3.57 \pm 0.11(4.1)$ \\
\hline 5-Isopropyl-2-methlbicyclo[3.1.0]hex-2-ene((-)-a-thujene) & $3.32 \pm 0.43(3.8)$ \\
\hline 1-Phenylethanone (acetophenone) & $1.75 \pm 0.09(2.0)$ \\
\hline 7-Methyl-3-methylene-octa-1,6-diene (seocalcitol) & $1.58 \pm 0.09(1.8)$ \\
\hline Decane & $0.92 \pm 0.01(1.0)$ \\
\hline 1-Isopropyl-4-methyl-1,3-cyclohexadiene (a-terpinene) & $0.81 \pm 0.03(0.9)$ \\
\hline Total volatiles & $86.48 \pm 5.43(100)$ \\
\hline
\end{tabular}

${ }^{11}$ The number in parenthesis was the percentage of each volatile divided by the total volatiles.

항균 및 항진균을 분석한 결과 오레가노의 효능이 가장 우수하다고 보고하였다. 또한 Shin 등(37)의 보고에 따르면 테르펜류는 산화 방지효과를 갖는 물질로 알려져 있어 테르 펜류 성분에 의해 산화 방지 등의 효과를 보이는 것으로 사료된다. Farag 등(14)의 연구에 따르면 0-cymene 및 thymol과 같은 페놀성 화합물이 활성산소종 형성을 억제한 다고 보고하였으며, $\mathrm{Li}$ 와 $\mathrm{Liu}(38)$ 의 연구는 $\mathrm{\gamma}$-terpinene과 a-pinene, limonene 등의 정유의 terpene계 성분이 높은 항산 화 활성을 보인다고 보고한 바 있어 오레가노 종자 추출물 의 항산화 활성은 phenol 화합물등의 phytochemical 물질 및 테르펜류 물질에서 기인한 것으로 사료된다.

\section{오레가노 종자 에탄올 추출물의 headspace oxygen 함량}

오레가노 종자 에탄올 추출물의 유지 내 산화 안정성을 알아보기 위해 headspace oxygen 함량을 측정한 결과를 Fig. 3 에 나타내었다. 오레가노 종자 에탄올 추출물을 첨가하지 않은 대조군에 비해 소모되는 산소의 비율이 유의적으로 감소하며 $(\mathrm{p}<0.001)$ 오레가노 종자 에탄올 추출물이 유지산 화에 영향을 미치는 것으로 나타났다. $6,12,18$ 시간의 열산 화로 대조군의 headspace oxygen 함량은 $18.5,15.1,12.4$ $\%$ 로 나타나 유의적으로 잔존 산소량이 감소 $(\mathrm{p}<0.05)$ 하는 데 비해 오레가노 종자 에탄올 추출물 $0.1 \mathrm{mg} / \mathrm{mL}$ 농도에서 $6,12,18$ 시간 열 산화 시 각각 $19.7,17.4,14.9 \%, 0.5 \mathrm{mg} / \mathrm{mL}$ 농도에서 각각 $18.6,16.6,13.8 \%, 1 \mathrm{mg} / \mathrm{mL}$ 농도에서 각각

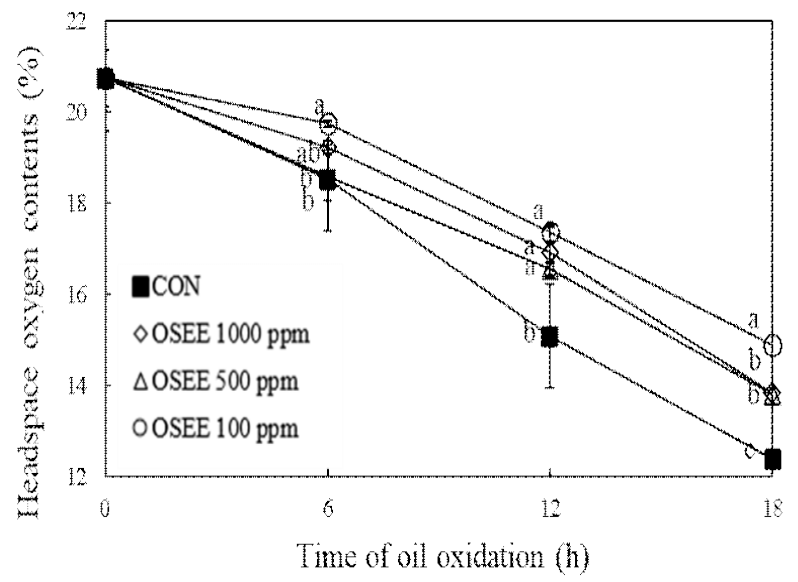

Fig. 3. Change of headspace oxygen content in corn oil added with oregano seed ethanol extract.

OSEE, oregano seed ethanol extract.

Different letters are significantly different at $\mathrm{p}<0.001$ among different treatment concentration each group.

$19.2,16.9,13.8 \%$ 로 관찰되어 오레가노 종자 에탄올 추출물 $0.1 \mathrm{mg} / \mathrm{mL}$ 농도 첨가가 열 산화 시간이 증가함에 따라 나타 나는 산소소모량을 감소시켜 적은 용량에서도 유지산화 안정성을 보이는 것으로 관찰되었다 $(\mathrm{p}<0.001)$. Asensio 등 (39)의 연구에 따르면 올리브오일에 오레가노 잎 추출물을 첨가하였을 때 지질 산화 과정을 지연시켜 저장 기간을 증가시킨다고 보고하였으며, Lolos 등(40) 연구에서도 대두 유를 이용한 튀김 시 오레가노 잎 추출물을 첨가할 경우 튀김에 흡수된 기름의 산화를 지연시켜 튀김의 신선도를 늘린다는 결과를 보고하였다. 따라서 본 연구에서도 유지 산화 시 산소 소모를 줄이는 효과를 관찰할 수 있어 오레가 노 종자 에탄올 추출물이 연속적인 유지산화를 지연시키는 효과가 있는 것을 확인할 수 있었다.

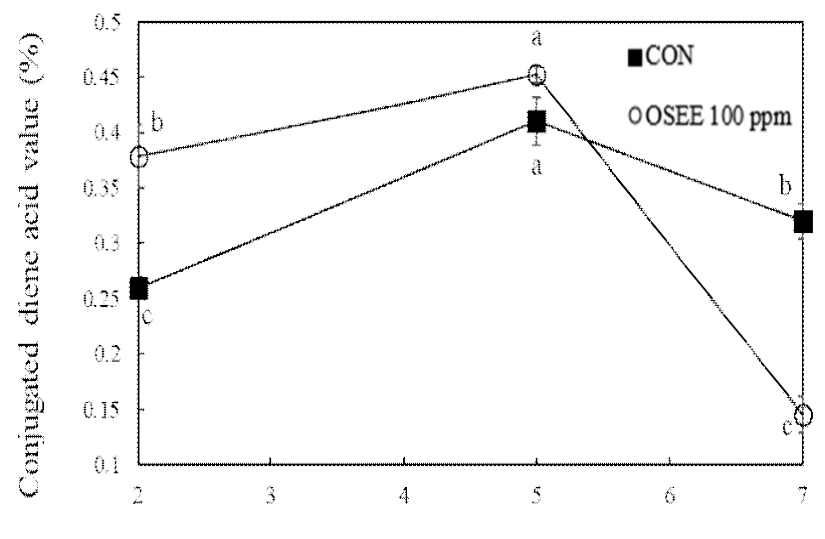

Time of oil oxidation (h)

Fig. 4. Change of conjugated dienoic acid value in $100^{\circ} \mathrm{C}$ corn oil added with or egano seed ethanol extract.

OSEE, oregano seed ethanol extract.

Different letters are significantly different at $p<0.05$ among different treatment time each group. * are significantly different at $p<0.05$ between control and oregano seed ethanol extract. 


\section{오레가노 종자 에탄올 추출물의 CDA가 및 $\mathrm{p}-\mathrm{AV}$}

유지가 산화되면서 형성하는 공액 이중결합을 측정하는 $\mathrm{CDA}$ 가 결과는 Fig. 4 와 같다. $2,5,7$ 시간 산화시킨 결과 시료가 첨가되지 않은 대조군의 $\mathrm{CDA}$ 양은 각각 $0.26,0.41$, $0.32 \%$ 로 측정되었다. 오레가노 종자 에탄올 추출물 100 $\mathrm{ppm}$ 첨가 군에서는 $0.38,0.45,0.14 \%$ 로 측정되었다. 대조군 과 비교하여 $100 \mathrm{ppm}$ 농도의 오레가노 종자 에탄올 추출물 첨가 군의 $\mathrm{CDA}$ 양이 7시간 이상 유지산화 시 발생되는 $\mathrm{CDA}$ 양을 유의적으로 2.3 배 감소하는 것으로 관찰되었다 $(\mathrm{p}<0.05)$. 그뿐만 아니라 유지의 산화 과정에서 만들어진 이차 산화 생성물을 측정한 $\rho-\mathrm{AV}$ 의 결과는 Fig. 5 와 같다. 유지 산화를 2, 5, 7시간 진행하였을 때 대조군의 $\mathrm{p}-\mathrm{AV}$ 는 각각 $12.63,50.35,165.37$ 로 측정되었으며, 오레가노 종자 에탄올 추출물을 $100 \mathrm{ppm}$ 첨가 시 각각 $3.19,36.90,38.83$ 으 로 측정되어 이차 산화 생성물에 대한 생성 억제가 우수한 것으로 나타났다.

이러한 식품 모델에서 유지산화 안정성에 관한 연구를 보면, 유제품에 오레가노 잎 추출물 첨가 시 conjugated diene의 함량이 유의적으로 감소함을 관찰하여 오레가노 잎 추출물 이 유제품의 보관 중에 산화를 효과적으로 방지 할 수 있다고 보고하였다(41). 다른 향신료 관련 산화 안정 성에 관한 연구로 샐러리 종자 $80 \%$ 에탄올 추출물을 첨가 한 수중유적형 유화계의 광산화 시 대조군에 비해 생성되는 conjugated dienoic acid의 양이 유의적으로 감소하였다고 보고한 바 있다(41). 본 연구결과, 유지산화 시에 생성되는 산화물 중 이차 산화 생성물에 대한 생성 억제가 대조군에 비하여 오레가노 종자 추출물 첨가 군이 유의적으로 우수한 것으로 관찰되어, 유지산화 시간이 증가될수록 효과를 보 이는 것으로 관찰되었다.

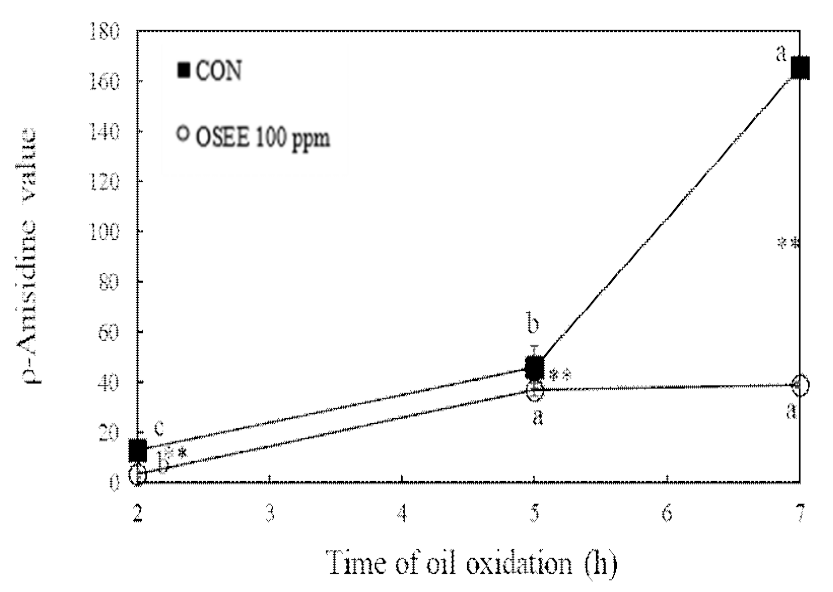

Fig. 5. Change of $\rho$-anisidine value in $100^{\circ} \mathrm{C}$ corn oil added with oregano seed ethanol extract.

OSEE, oregano seed ethanol extract.

Different letters are significantly different at $p<0.05$ among different treatment time each group. ** are significantly different at $p<0.01$ between control and oregano seed ethanol extract.

\section{요 약}

합성 산화방지제에 대한 불안함으로 인해 천연에서 추출 한 식품 산화방지제에 대한 관심이 커지고 있으나 그 종류 가 한정적이므로 본 연구에서는 $80 \%$ 에탄올을 용매로 하여 추출한 오레가노 종자의 산화 방지 활성과 유지 산화 안정 성을 in vitro assay와 실제 유지산화 시스템에서 평가해 보고자 하였다. 산화 방지를 측정하고자 실시한 DPPH 라디 칼 소거활성 결과 $125 \mathrm{\mu g} / \mathrm{mL}$ 에서 $84.62 \%$ 소거 활성을 보였 고 $\mathrm{ABTS}$ 양이온 라디칼 소거 활성 결과 $125 \mathrm{\mu g} / \mathrm{mL}$ 에서 $32.22 \%$ 소거 활성을 보였으며 이는 농도 의존적인 라디칼 소거활성을 나타내었다. 총 페놀 함량은 $264.64 \mu \mathrm{g} / \mathrm{mL}$ tannic acid equivalent/g extract, FRAP 환원력은 $339.78 \mu$ $\mathrm{g} / \mathrm{mL}$ ascorbic acid equivalent/g extract로 관찰되어 오레가 노 종자 에탄올 추출물의 산화 방지 측정법들과 총 페놀 함량은 유의적인 상관관계를 보였으며, ORAC가 결과 농도 의존적으로 상승하는 산화 방지능을 보였다. 유지 산화 안 정성 측정을 위해 옥수수기름에 오레가노 종자 에탄올 추출 물을 첨가하여 18 시간 열 산화 시켰을 때 headspace oxygen 은 $0.1 \mathrm{mg} / \mathrm{mL}$ 농도에서 $14.9 \%$ 로 대조군보다 $2.5 \%$ 높게 나타났고, $100^{\circ} \mathrm{C}$ 에서 7 시간 산화시킨 결과 $\mathrm{CDA}$ 의 양은 대조군 보다 $56.3 \%$ 낮았다. 이차 산화물을 측정하는 $\rho-A V$ 는 대조군에 비해 $76.5 \%$ 적게 생성되었다. 또한 향기성분을 분석한 결과 주요 휘발성 물질은 limonene, linalool, o-cymene, thymol, a-pinene, $\gamma$-terpinene 등으로 분석되었다. 본 연구 결과 오레가노 종자 에탄올 추출물이 산화 방지 활성, 유지 산화 안정성 등에 우수한 효과를 나타낸 것으로 판단되며 향후 유지 식품 혹은 유지가 다량 함유된 가공식품의 제조 시 산화를 방지하기 위한 목적으로서 합성 산화방지제의 역할을 대체할 수 있을 것으로 사료된다.

\section{감사의 글}

본 연구는 2017년도 강원대학교 대학회계 학술연구조성 비(관리번호-620170125)에 의해 수행되었습니다.

\section{References}

1. Choe EO, Lee JY (1998) Thermooxidative stability of soybean oil, beef tallow and palm oil during frying of steamed noodles. Korean J Food Sci Technol, 30, 288-292

2. Takahashi O, Sakamoto Y, Hiraga K (1985) Lung hemorrhagic toxicity of butylated hydroxyanisole in the rat. Toxicol Lett, 27, 15-25

3. Branen AL (1975) Toxicology and biochemistry of 
butylated hydroxyanisole and butylated hydroxytoluene, J Am Oil Chem Soc, 52, 59-63

4. Leibovitz BE, Siegel BV (1980) Aspects of free radical reactions in biological systems: aging. J Gerontol, 35, 45-56

5. Freeman BA, Crapo JD (1982) Biology of disease: free radicals and tissue injury. Lab Invest, 47, 412-426

6. Fridovich I (1978) The biology of oxygen radicals. Science, 201, 875-880

7. Lynch RE, Fridovich I (1978) Effects of superoxide on the erythrocyte membrane. J Biol Chem, 253, 1838-1845

8. Hitokoto H, Morozumi S, Wauke T, Sakai S, Kurata H (1980) Inhibitory effects of spices on growth and toxin production of toxigenic fungi. Appl Environ Microbiol, 39, 818-822

9. Karapinar M, Aktug SE (1987) Inhibition of foodborne pathogens by thymol, eugenol, menthol and anethole. Int J Food Microbiol, 4, 161-166

10. Kurita N, Miyaji M, Kurane R, Takahara Y (1981) Antifungal activity of components of essential oils. Agric Biol Chem, 45, 945-952

11. Shahidi F, Ambigaipalan P (2015) Phenolics and polyphenolics in foods, beverages and spices: Antioxidant activity and health effects - A review. J Funct Foods, 18, 820-897

12. Chaibi A, Ababouch LH, Belasri K, Boucetta S, Busta FF (1997) Inhibition of germination and vegetative growth of Bacillus cereus $\mathrm{T}$ and Clostridium botulinum 62A spores by essential oils. Food Microbiol, 14, 161-174

13. Dorman HJD, Deans SG (2000) Antimicrobial agents from plants: antibacterial activity of plant volatile oils. J Appl Microbiol, 88, 308-316

14. Farag RS, Badei AZMA, Hewedi FM, El Baroty GSA (1989) Antioxidant activity of some spice essential oils on linoleic acid oxidation in aqueous media. J Am Oil Chem Soc, 66, 792-799

15. Almeida-Doria RF, Regitano-d'arce MAB (2000) Antioxidant activity of rosemary and oregano ethanol extracts in soybean oil under thermal oxidation. Food Sci Technol, 20, 197-203

16. Deleanu M, Popa EE, Popa ME (2018) Chemical composition and active properties evaluation of wild oregano (Origanum Vulgare) and ginger (Zingiber Officinale-Roscoe) essential oils. Rev Chim Bucharest, 69, 1927-1933

17. Blois MS (1958) Antioxidant determinations by the use of a stable free radical. Nature, 181, 1199-1200
18. Re R, Pellegrini N, Proteggente A, Pannala A, Yang M, Rice-Evans C (1999) Antioxidant activity applying an improved ABTS radical cation decolorization assay. Free Radical Biol Med, 26, 1231-1237

19. Prior RL, Hoang H, Gu L, Wu X, Bacchiocca M, Howard L, Hampsch-Woodill M, Huang D, Ou B, Jacob R (2003) Assays for hydrophilic and lipophilic antioxidant capacity (oxygen radical absorbance capacity $\left(\mathrm{ORAC} \mathrm{C}_{\mathrm{FL}}\right)$ ) of plasma and other biological and food samples. J Agric Food Chem, 51, 3273-3279

20. Benzie IFF, Strain JJ (1996) The ferric reducing ability of plasma (FRAP) as a measure of "antioxidant power": the FRAP assay. Anal biochem, 239, 70-76

21. Folin O, Denis W (1912) A new colorimetric method for the determination of vanillin in flavoring extracts. Ind Eng Chem, 4, 670-672

22. Kim MA, Han CH, Lee JC, Kim MJ (2017) Antioxidant properties and oxidative stability of celery seeds ethanol extract using in vitro assays and oil-in-water emulsion. Korean J Food Sci Technol, 49, 480-485

23. AOCS (1980) Official and tentative methods of the AOCS. $3^{\text {rd }}$ ed, American oil chemists' society press, Champaign, IL, USA, Method Cd 18-90

24. AOCS (1990) Official and tentative methods of the AOCS. $4^{\text {th }}$ ed, American oil chemists' society press, Champaign, IL, USA, Method Ti la-64

25. Rhim TJ, Choi MY (2009) The antioxidative effects of oregano (Origanum majorana L.) extracts. Korean J Plant Res, 22, 425-430

26. Cha WS, Kim JH, Lee KH, Kwon HJ, Yoon SJ, Chun SS, Choi UK, Cho YJ (2006) Antioxidative and inhibition activities on Helicobacter pylori of spice extracts. J Korean Soc Food Sci Nutr, 35, 315-320

27. Kim JH, Kwon JH, Lee KH, Chun SS, Kwon OJ, Woo HS, Cho YJ, Cha WS (2006) Inhibitory effect against Helicobacter pylori and biological activity of thyme (Thymus vulgaris L.) extracts. J Korean Soc Appl Biol Chem, 49, 243-247

28. Cho BY, Lee JH, Ra MJ, Kim SY, Kang IJ, Han KC, Lee $\mathrm{OH}$ (2016) Analysis of pectolinarin content and antioxidant activity in Cirsium setidens Nakai by cultivars. J Food Hyg Saf, 31, 210-215

29. Park SJ (2014) Antioxidant and anti-adipogenic effects of ethanolic extracts from Lxeris dentata Nakai. Korean J Culinary, 20, 133-142

30. Kratchanova M, Denev P, Ciz M, Lojek A, Mihailov A (2010) Evaluation of antioxidant activity of medicinal 
plants containing polyphenol compounds. Comparison of two extraction systems. Acta Biochim Pol, 57, 229-234

31. Su L, Yin JJ, Charles D, Zhou K, Moore J, Yu LL (2007) Total phenolic contents, chelating capacities, and radical-scavenging properties of black peppercorn, nutmeg, rosehip, cinnamon, and oregano leaf. Food Chem, 100, 990-997

32. Ahn CK, Lee YC, Yeom CA (2000) Antioxidant and mixture effects of curry spices extracts obtained by solvent extraction. Korean J Food Sci Technol, 32, 491-499

33. Surveswaran S, Cai YZ, Corke H, Sun M (2007) Systematic evaluation of natural phenolic antioxidants from 133 Indian medicinal plants. Food Chem, 102, 938-953

34. Zheng W, Wang SY (2001) Antioxidant activity and phenolic compounds in selected herbs. J Agric Food Chem, 49, 5165-5170

35. Lopez P, Sanchez C, Batlle R, Nerin C (2007) Vaporphase activities of cinnamon, thyme, and oregano essential oils and key constituents against foodborne microorganisms. J Agric Food Chem, 55, 4348-4356

36. Baratta MT, Dorman HJD, Deans SG, Biondi DM, Ruberto G (1998) Chemical composition, antimicrobial and antioxidative activity of laurel, sage, rosemary, oregano and coriander essential oils. J Essent Oil Res, $10,618-627$
37. Shin YH, Kim HJ, Lee JY, Cho YJ, An BJ (2012) Major compound analysis and assessment of natural essential oil on anti-oxidative and anti-microbial effects. J Life Sci, 22, 1344-1351

38. Li GX, Liu ZQ (2009) Unusual antioxidant behavior of $a-$ and $\gamma$-terpinene in protecting methyl linoleate, DNA, and erythrocyte. J Agric Food Chem, 57, 3943-3948

39. Asensio CM, Nepote V, Grosso NR (2011) Chemical stability of extra virgin olive oil added with oregano essential oil. J Food Sci, 76, S445-S450

40. Lolos M, Oreopoulou V, Tzia C (1999) Oxidative stability of potato chips: effect of frying oil type, temperature and antioxidants. J Sci Food Agric, 79, $1524-1528$

41. Boroski M, Giroux HJ, Sabik H, Petit HV, Visentainer JV, Matumoto-Pintro PT, Britten M (2012) Use of oregano extract and oregano essential oil as antioxidants in functional dairy beverage formulations. LWT-Food Sci Technol, 47, 167-174 